\title{
The Application of Organizers as an Efficient Technique in ESP Textbooks Development
}

\author{
Abutaleb Iranmehr \\ Shahrood University of Technology, Shahrood, Iran \\ Email: a_iranmehr946@yahoo.com \\ Hossein Davari \\ Payam Nour University, Damghan, Iran \\ Email: hdavari1358@yahoo.com \\ Seyyed Mahdi Erfani \\ Damghan University, Damghan, Iran \\ Email: smerfani@yahoo.com
}

\begin{abstract}
The crucial role of English for Specific Purposes (ESP) textbooks, especially in situations where English is taught as a foreign language (EFL), and also their role as almost the only source of English language seem undeniable. In Dudley-Evans and St. John's (1998) words, considering such situations where learners need to extract their information from English-medium subject textbooks, a reading-only course could be suitable, but such textbooks should be developed in a way to maximize learners' exposure to language, to meet their needs, to increase their motivations and to facilitate their learning and recall of information. Therefore, in ESP materials development, graphic organizers, defined as visual displays in which the information is converted into a diagrammatic representation of important key words and concepts associated with the main study topic, could be used as an innovative technique to provide better learning opportunities and facilitate students' learning processes. Thus, this paper is an attempt to present the advantages of using graphic organizers as an advantageous technique in developing ESP textbooks as well as to report the personal observations and experiences of the researchers in teaching ESP through graphic organizers and also to give some useful recommendations to ESP teachers, textbooks designers and materials developers to resort to this efficient technique.
\end{abstract}

Index Terms-graphic organizers, ESP, textbooks development

\section{INTRODUCTION}

Playing a crucial role in any ESP classroom, textbooks should be developed in a way that can easily meet the learners' needs, increase their motivations and facilitate their learning and recall of information. In Dudley-Evans and St. John's (1998) words, in situations where English is a foreign and not a second language, the ESP classroom may be almost the only source of English and in such situations materials then play an important role in exposing learners to the language. In their words, in such situations, a reading-only course could meet the learners' needs and interests as well as the program's goals.

Considering the current status of ESP textbooks in Iranian academic context reveals that while it has been quite a while since their introduction to the Iranian university system, all of which developed to improve the learners' reading skill, may hardly ever meet the actual needs of Iranian university students as well as educationalists and curriculum designers (see Erfani, et al., 2009; Farhady, 2005; Riazi, 2005).

Dealing with the significant shortcomings of Iranian ESP textbooks, Erfani et al. (2009), Iranmehr et al. (2010 a) and Shokouhi (2005) introduce the lack of useful and efficient approaches, strategies and techniques as one of the main serious drawbacks of ESP textbooks. In this regard, criticizing the lack of diversity of exercises, drills and activities, Soleimani (2005) maintains that many common reading strategies have been neglected.

In Shokouhi's (2005) words, also the dominance of inadequate methods or approaches like Grammar-Translation Method has led to ignoring some efficient approaches, strategies and techniques in Iranian ESP textbooks development.

The researchers, conceiving the inadequacy of the current strategies in ESP textbooks such as the necessity of integrating the efficient strategies and techniques in reading comprehension as well as understanding the significant impact of graphic organizers as a strategy providing learning opportunities (Dehnad, 2005), facilitating learning and recall of information (Chiang, 2004), and strengthening the reading comprehension ability of language learners (McNamara, 2007), have intended to present and introduce this efficient strategy to be used in Iranian ESP textbooks development to reduce the inefficiency of the current framework which is dominant on these textbooks. 


\section{REVIEW OF LITERATURE}

In this part, before dealing with the concept of graphic organizers, their functions and types as well as the reports available on its efficiency on reading comprehension, it seems necessary to have a short glance at the importance of ESP materials development in addition to the current status of Iranian ESP textbooks.

Enumerating the main components of any curriculum, Richards (2001) introduces materials as one of them and certainly ESP as a trend of English language teaching (ELT) is not an exception to the rule. In his words, ESP materials should be not only a source of language, but a source of motivating and stimulating learning support. In other words, ESP as a material-led movement (Dudley-Evans \& St. John, 1998) has aimed at providing the teaching textbooks to satisfy the learners' needs and interests as well as the program's objectives.

In spite of passing about twenty-six years form the introduction of ESP textbooks development in Iranian academic context, as noted, they are still suffering from some serious drawbacks which have been studied, especially in recent years, more or less by Iranian scholars and practitioners.

To put it simply, we can claim that besides the shortcomings, including issues related to curriculum development, teachers' misunderstanding or inattention to the real position of ESP, lack of needs analysis, inefficient assessment, etc., there is no doubt that the ESP textbooks are also suffering from serious shortcomings.

According to Erfani et al. (2011), in most Iranian ESP textbooks, language focus is emphasized and no attention is given to skills and strategies such as skimming, scanning, guessing meaning from the context, graphic organizers, etc. Soleimani (2005) also believes that the uniformity of one single pattern in these books means imposing an inflexible structure on learners to follow.

Concerning such drawbacks and shortcomings, Farhady (2005) clearly asserts that current practice in Iranian ESP materials development should fundamentally be redesigned and Iranmehr et al. (2010 a) call for the reengineering of Iranian ESP textbooks.

\section{A. Graphic Organizers}

Graphic organizers as visual displays that depict relationships between facts, terms and ideas within a learning task (Hall \& Strangman, 2002) include maps, webs, graphs, charts, frames and clusters (Willis, 2008). In her words, they can increase comprehension, organization, summarizing, prioritizing and analysis by helping students construct and visualize relationships.

According to Ben-David (2002) graphic organizers are useful in organizing information to make it easier to understand and learn. In fact, constructing graphic organizers helps learners discover how knowledge is related to prior knowledge in content areas and this has been viewed as an essential part of reading comprehension skill. According to Trabasso and Bouchard (2002), graphic organizers as a cognitive strategy can improve reading comprehension. Griffin et al. (1995) maintain that graphic organizers as a strategy can help readers organize text contents effectively. Providing three reasons why language teachers should use graphic organizers in their classrooms, Ellis (2004) classifies them as following: first, learners are considerably more likely to understand and remember the content subject since graphic organizers help them identify what is important to know about a text; second, because the semantic processing demands are minimized, teachers can address the content at more sophisticated or complex levels; third, learners are more likely to become strategic readers as they recognize the patterns of thinking, constructing and using graphic organizers. McNamara (2007) also introduces graphic organizer as a strategy to organize, restructure and synthesize the text content.

Research findings (see Mohammadi et al., 2010; Chiang, 2004) along with some theoretical backgrounds (see Tarquin \& Walker, 1997; Willis, 2008) reveal that using graphic organizers as a strategy facilitates reading comprehension. In addition, empirical studies support the benefit of graphic strategies in helping readers' memorization and comprehension of descriptive text contents (Alverman, 1981), concept acquisition (Robinson et. al., 1998), science concept learning (Novak \& Musonda, 1991; Schmid \& Telaro, 1991), and learning from texts (Hauser et. al., 2006).

To sum up, graphic organizers are excellent tools for learning the structure of thinking skills. A graphic organizer provides a powerful visual picture of information and allows the mind "to see" patterns and relationships.

Conceiving such importance and efficiency, it is strongly believed that this strategy can be used in teaching ESP reading comprehension as well as developing ESP reading materials. Since the Iranian ESP textbooks are developed with a special focus on reading comprehension, this strategy can certainly be integrated in these textbooks.

\section{B. Types of Graphic Organizers}

There are many kinds of graphic organizers and they are classified in various ways. According to one of the most popular classifications, graphic organizers can be categorized by the different thinking skills they utilize:

I. Describing:

(a) A concept map is a special form of a web diagram for exploring knowledge and gathering and sharing information.

(b) A mind map is a diagram used to represent words, ideas, tasks, or other items linked to and arranged around a central key word or idea.

II. Comparing / contrasting:

(a) Venn diagrams show all hypothetically possible logical relations between a finite collection of sets. 
(b) A Double Cell Diagram is an excellent substitute for a Venn diagram for comparing likenesses and differences.

III. Classifying:

(a) The hierarchy chart (also known as a structure chart) shows the relationship of various units. It groups items (things, people, places, events, ideas, etc.) into categories.

IV. Sequencing:

(a) Linear string describes a sequence of events, stages, phases, actions and outcomes.

(b) Sequence chart includes connected boxes of a sequence chart that shows a progression, series, or succession of information.

V. Reflecting:

(a) KWL is a three-column chart whose specific labels for each column are" What do you KNOW?", What do you WANT to know?" and "What have you LEARNED?". This is useful when you are faced with new or difficult information.

(b) PMI shows positive, negative, and interesting attributes of a subject, concept, topic, solution, etc., in order to determine the nature of the outcome and whether it will be worth continuing or not.

\section{RESEARCHERS' OBSERVATION AND EXPERIENCES OF TEACHING ESP THROUGH GRAPHIC ORGANIZERS AND THEIR SUGGESTIONS FOR FURTHER}

To check the efficiency of using graphic organizers on ESP reading comprehension, the researchers tried to study an experimental research (see Iranmehr et al., 2010 b). In short, not only did the findings reveal that statistically the experimental group outperformed, but also our observations showed that using this strategy as an innovative one helped learners improve ESP reading comprehension and engage more actively in the class.

Considering the fact that this study was limited to only some types of graphic organizers, it is suggested that similar studies be conducted with other types of graphic organizers. The need is also felt to carry out similar studies to investigate the effects of graphic organizers at higher and lower levels of language proficiency. Moreover, more comprehensive studies could be done to investigate the effect of graphic organizers on other skills specially writing. Last but not the least, it is recommended to ESP teachers and materials developers not to restrict themselves to some common traditional but ineffective approaches and methods.

\section{AN ESP SAMPLE LESSON FURNISHED WITH SOME TYPES OF GRAPHIC ORGANIZERS}

Conceiving the efficiency of graphic organizers along with the deficiency of the current ESP textbooks, the researchers tried to integrate them into their teaching. To do so, they furnished the available lessons with some patterns of graphic organizers; one of these redesigned lessons is presented here.

\section{MATTER}

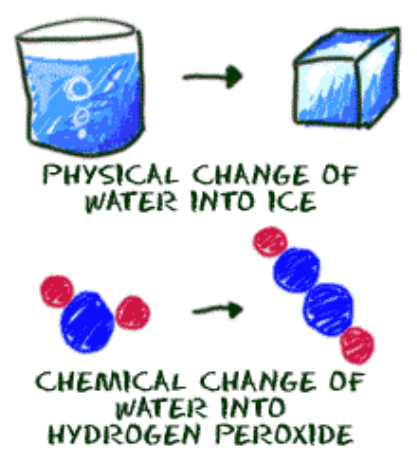

1. Matter is everything around you. Matter is anything made of atoms and molecules. Matter is anything that has a mass. As of 1995, scientists have identified five states of matter. They are solids, liquids, gases, plasmas, and a new one called Bose-Einstein condensates. The first four have been around a long time. The scientists who worked with the Bose-Einstein condensate received a Nobel Prize for their work in 1995.

2. Changing states of matter is about changing densities, pressures, temperatures, and other physical properties. The basic chemical structure does not change. As the temperature of matter increases, particles move faster because they have more energy. In a solid, particles have less energy, are tightly packed together (dense) and do not move very much. Solids have a definite shape and volume. In a liquid, particles have more energy, are less tightly packed (less dense), and can move freely. Liquids have definite volume but no definite shape (instead, they take on the shape of the container). The particles in a gas have the most energy and are free to move around and so spread out rapidly. Gases do not have a definite shape or volume and expand to fill the entire container. Thus, as the temperature of matter increases, its density decreases (particles get farther apart).

3. All matter can move from one state to another. It may require very low temperatures or very high pressures, but it can be done. Phase changes happen when certain points are reached. Sometimes a liquid wants to become a solid. Scientists use something called a freezing point to measure when that liquid turns into a solid. There are physical effects that can change the freezing point. Pressure is one of those effects. When the pressure surrounding a substance goes up, the freezing point also goes up. That means it's easier to freeze the substance at higher pressures.

4. Atoms in a liquid have more energy than the atoms in a solid. The easiest energy around is probably heat. There is a magic temperature for every substance called the melting point. When a solid reaches the temperature of its melting 
point it can become a liquid. For water the temperature has to be a little over zero degrees Celsius. If you were salt, sugar, or wood your melting point would be higher than water.

Task 1: Use the passage you have studied to complete the following.

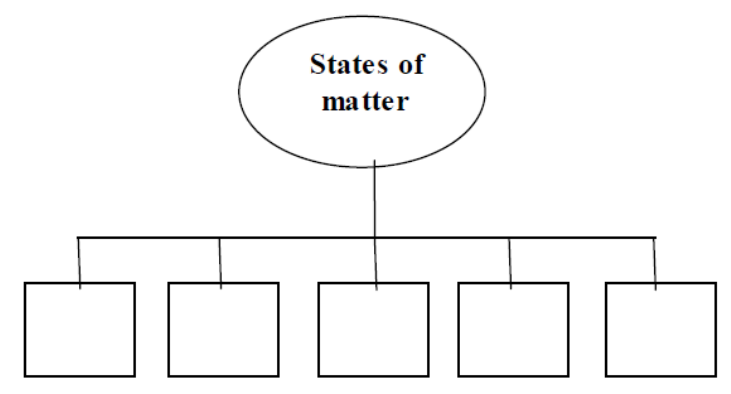

Task 2: Use the passage to complete the following table.

\begin{tabular}{|l|l|l|l|}
\hline state & \multicolumn{1}{|c|}{ movement } & proximity & shape/volume \\
\hline & Very fast & & \\
\hline & & Very tightly packed & \\
\hline & & & \\
\hline
\end{tabular}

Task 3 Write the properties of liquids in the boxes:

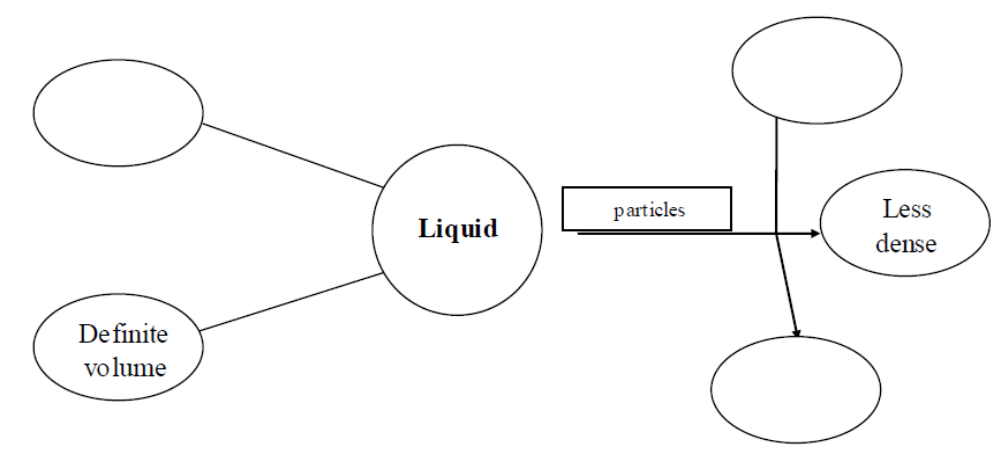

Task 4: Use the chart and write the similarities and differences of three types of matter:

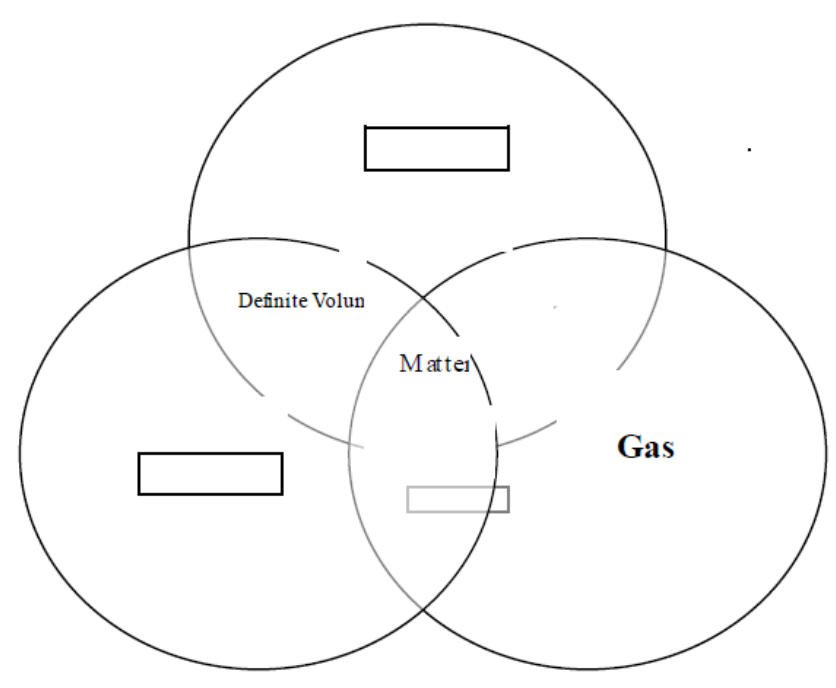


Task 5: Write the sequence of changing states of matter:

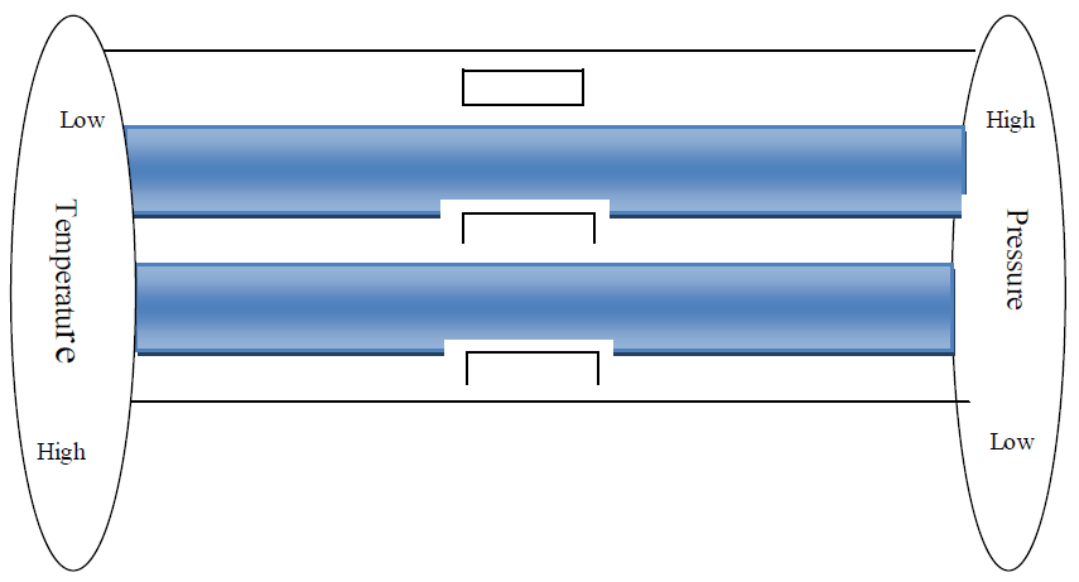

Task 6: Put the following words in their appropriate places.

temperature / pressure / freezing point / boiling point

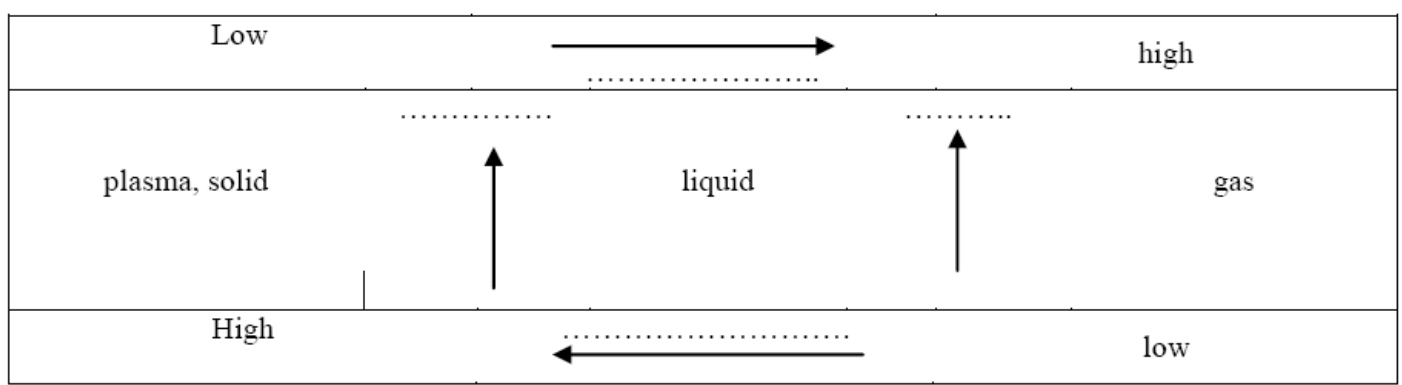

Task 7: According to the passage write the properties of melting and freezing points in the boxes:

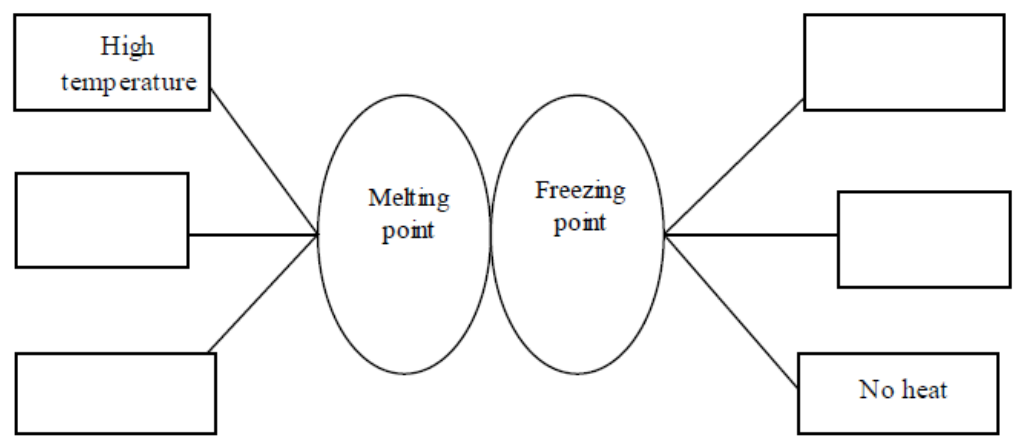

\section{REFERENCES}

[1] Alvermann, D. E. (1981). The compensatory effect of graphic organizers on descriptive text. Journal of Educational Research. $75,44-48$.

[2] Ausubel, D. P. (1960).The use of advance organizers in the learning and retention of meaningful behavior. Journal of Educational Psychology, 51,267-272.

[3] Ben-David, R. (2002). Enhancing comprehension through graphic organizers. Unpublished master's thesis, Kean University (ERIC Document Reproduction service No. ED461907).

[4] Chiang, T. Y. (2004). A case study on concept mapping as an adjunct aid for EFL reading comprehension and recall. Unpublished master's thesis. Southern Taiwan University of technology, Taiana, Taiwan.

[5] Dehnad, A. (2005). Graphic organizers as an effective study technique in an ESP class. In Kiani \& Khayamdar (Eds.) Proceedings of the First National ESP/EAP Conference, vol. II, Tehran, SAMT Publication.

[6] Dudley-Evans, T. \& St. John, M. J. (1998). Developments in English for Specific Purposes: A multi-disciplinary approach. Cambridge University Press.

[7] Ellis, E. (2004). Makes sense strategies overview. Retrieved 10/11/2010., from Graphicorganizers.com 
[8] Erfani, S. M., Iranmehr, A. \& Davari, H. (2009). Iranian ESP Textbooks Drawbacks: A Critical Study. The First International Conference "ESP in Asia", China.

[9] Erfani, S. M., Iranmehr, A. \& Davari, H. (2011). Deepening ESP reading comprehension through visualization. Journal of Language Teaching and Research, 2(1), 270-273.

[10] Farhady, H. (2005). Reflections on and Directions for ESP Materials Development in SAMT, In Kiani \& Khayamdar (Eds.) Proceedings of the First National ESP/EAP Conference, vol. III, Tehran, SAMT Publication.

[11] Griffin, C. C., Molane, L. D. \& Kammenui, E. J. (1995). Effects of graphic organizer instruction on fifth-grade students. Journal of Educational research, 89 (2), 98-107.

[12] Hall, T. \& strangman, N. (2002). Graphic organizers. National center on assessing the general curriculum. Retrived Nov. 23, 2009 from http://www.case.org/ncac.

[13] Hauser, S., Nuckles, M., \& Renkl, A. (2006). Supporting concept mapping for learning from text. In S. A. Barbara, K. E. Hay, $\&$ D. T Hickey (Eds.), Proceedings of the Seventh International Conference of the Learning Sciences (pp. 243-249). Mahwah, NJ: Lawrence Eelbaum Associates, Inc.

[14] Iranmehr, A., Erfani, S. M. \& Davari, H. (2010). A call for the reengineering of Iranian ESP textbooks. Sino-Us English Teaching, 7(7), 23-30.

[15] Iranmehr, A., Erfani, S. M. \& Davari, H. (2010). The effect of using graphic features on general English reading comprehension ability of Iranian university students. In the First Conference on New Perspectives in ELT, Linguistics \& Literature, Sanandaj, Iran.

[16] McNamara, D. S. (2007). Reading Comprehension strategies: Theories, Interventions, and Technologies. Mahwah, NJ: Lawrence Erlbaum Associates, Inc.

[17] Moreillon, J. (2007), Collaborative strategies for teaching reading comprehension strategies, American library Association, Chicago.

[18] Mohammadi, M., Moeinikia, M. \& Zahed-Babelan, A. (2010). The Role of Advance oraganizer on English language learning as a second language. Presented In WCES, Procedia.

[19] Novak, J. D., \& Musonda, (1991). A twelve year longitudinal study of science concept learning. American Educational Research Journal, 28, 117-153.

[20] Riazi, A. (2005). Features of Quality EAP Textbooks: Insights from Literature and Book Reviews, In Kiani \& Khayamdar (Eds.) Proceedings of the First National ESP/EAP Conference, vol. I, Tehran, SAMT Publication.

[21] Richards, J. C. (2001). Curriculum development in language teaching. Cambridge University Press.

[22] Robinson, D. H., Katayama, A. D., Dubois, N. F. \& De Vaney, T. (1998). Interactive effects of graphic organizers and delayed review on concept acquisition. Journal of Experimental education, 67, 17-31.

[23] Schmid, R. F., \& Telaro, G. (1991). Concept mapping as an instructional strategy for high school biology. Journal of Educational Research, 84, 78-85.

[24] Shokouhi, H. (2005). A New Discourse Plan for the Iranian University ESP Textbooks. In Kiani G. R. \& Khayamdar, M. (Eds.) Proceedings of the First National ESP/EAP Conference, vol. III, Tehran, SAMT Publication.

[25] Soleimani, H. (2005). EAP in Iran: Drawbacks of SAMT EAP Textbooks, In Kiani \& Khayamdar (Eds.) Proceedings of the First National ESP/EAP Conference, vol. III , Tehran, SAMT Publication.

[26] Tarquin, P. \& Walker, S. (1997). Creating Success in Classroom! Visual Organizers and How to Use Them. Teachers Ideas Press.

[27] Trabasso, T. \& Bouchard, E. (2002). Teaching readers how to comprehend text strategically. In C. C. Block \& M. Pressley (Eds.), Comprehension instruction: Research-based best practices (176 -202). New York: Guilford.

[28] Willis, J. (2008). Teaching the brain to read: strategies for improving fluency, vocabulary and comprehension. Association for Supervision and Curriculum development. Alexandria, Virginia, USA.

Abutaleb Iranmehr received his MA in TEFL in 1998 from Teacher Training University, Tehran, Iran. He is currently a lecturer of Shahrood University of Technology, Iran. His interests include ESP, materials development, teaching methodology and psycholinguistics and has published and presented papers in these areas.

Hossein Davari received his MA in linguistics in 2005 from Tarbiat Modares University (TMU), Tehran, Iran, and his MA in TEFL in 2010 from Payame Nour University (PNU). He is a lecturer of PNU, Damghan, Iran. His interests include materials development, sociolinguistics, lexicography \& ESP and has published and presented papers in these areas.

Seyyed Mahdi Erfani received his MA in linguistics in 1993 from Ferdousi University, Mashad, Iran. He is currently a lecturer of Damghan University, Iran. His interests include ESP, machine translation, materials development \& sociolinguistics and has published and presented papers in these areas. 